\title{
Electrophilic Cyclization of (Z)-Thiobutenynes: Synthesis of 3-Iodothiophenes
}

Amanda S. Santana, ${ }^{1}$ Nadla S. Cassemiro, ${ }^{1}$ Diego B. de Carvalho, ${ }^{1}$ Palimécio G. Guerrero Jr, ${ }^{2}$ Sandro L. Barbosa, ${ }^{3}$ Luiz H. Viana, ${ }^{1}$ Gabriela R. Hurtado, ${ }^{* 1}$ Adriano C. M. Baroni ${ }^{* 1}$

${ }^{1}$ Dep. de Farmácia-Bioquímica e Química - Univ. Federal de Mato Grosso do Sul - UFMS, Campo Grande/MS - Brasil.

${ }^{2}$ Lab. de Síntese Orgânica e Produtos Naturais, Depto de Química e Biologia, Univ. Tecnológica Federal do Paraná, UTFPR, Curitiba/PR, Brasil.

${ }^{3}$ Dep.Farmácia-Bioquímica, Univ.Federal dos Vales do Jequitinhonha e Mucuri, Diamantina/MG - Brasil. *gabihurt@yahoo.com, *adriano.baroni@ufms.br

Keywords: (Z)-thiobutenynes, iodocyclization, 3-iodothiophenes

\section{INTRODUCTION}

Heteroaromatic organic compounds containing the thiophenic structural unit has been isolated from natural sources like animals and plants. They are also found in synthetic compounds such as agrochemicals, pharmaceuticals, photographic and electronics products. ${ }^{1}$ This heterocycle is also widely used in Medicinal Chemistry in design of new drugs, due it is considered a classic bioisoster of the benzenic and furanic rings. ${ }^{2}$

\section{RESULTS AND DISCUSSION}

For the synthesis of the 3-iodothiophenes type 4 , iodocyclization reactions were performed using $\mathrm{I}_{2}$ as electrophilic source in $\mathrm{CH}_{2} \mathrm{Cl}_{2}$ and (Z)-thiobutenynes 1a-g. This methodology applies well to the synthesis of trisubstituted 3-iodothiophenes (compounds 4a-d, Table 1), but it is not efficient for the synthesis of disubstituted 3-iodothiophenes 4 e-g. In this case, the unwanted olefins 5e-g were formed (route b, Scheme 1). After an exhaustive investigation of reaction conditions with different solvents (THF, $\mathrm{CH}_{3} \mathrm{CN}, \mathrm{CHCl}_{3}, \mathrm{EtOH}$ ) and different temperatures, the best condition found to prepare thiophenes $4 \mathrm{e}-\mathrm{g}$ is one that employs $I_{2} \quad(1,1$ equiv), and $1,2-$ dichloroethane as solvent at $70^{\circ} \mathrm{C}$ (route a, Scheme 1, Table 1).

Scheme 1. Proposed mechanism for the reaction of iodocyclization
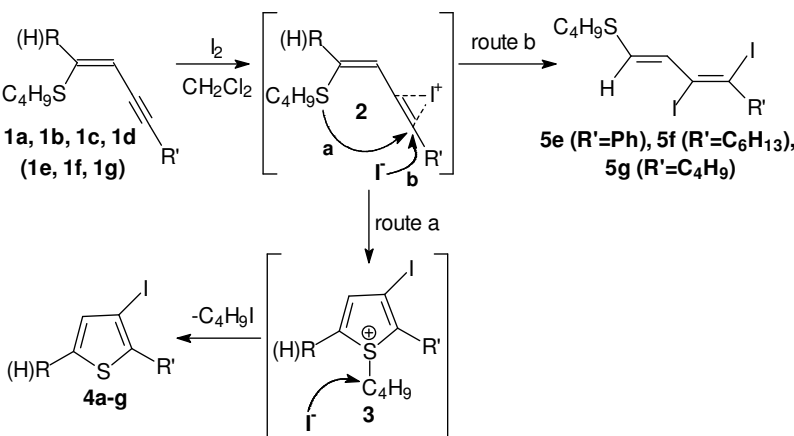

Table 1. Products obtained

Time (min) /
Yield(\%)

aproduct isolated after purification by chromatographic column.

\section{CONCLUSION}

The methodologies developed are efficient to prepare di and trisubstituted 3-iodothiophenes in good yields. Studies are being conducted to demonstrate the generality of the methodologies.

\section{ACKNOWLEDGEMENTS}

FUNDECT-MS, PROPP-UFMS, CNPq

\section{REFERENCES}

${ }^{1}$ Kaniskan, N.; Elmali, D.; Civcir, P. U. Arkivoc 2008, 17, e referências citadas.

${ }^{2}$ Wermuth, C. G. The Practice of Medicinal Chemistry, $2^{\text {nd }}$ ed.,

Elsevier - Academic Pres, 2004. 